\title{
A List of Chaoben in the Author's Personal Collection Used in This Study
}

The majority of items in this list are handwritten, unless otherwise noted. A few are woodblock prints or lithographs. Many of the handwritten chaoben had no cover or title page, in which case I use the first few words on the first readable page as the title. The items are listed below in alphabetical order based on the English-language titles.

This list includes all the chaoben mentioned in this book, fifty-seven titles, but my full collection comprises about 250 chaoben. For a more complete discussion of the contents of the ones discussed in this book, please see the notes to the respective chapters.

Anhui Collection [Anhui ji 安徽集]. This consists of nine handwritten volumes, dating from 1896, 1924, 1930, 1931, 1932, and 1940. They include many ritual books [keyiben 科義本] and other material as well as what appears to be personal reflections. One of the copyists whose name is on later volumes was Cheng Zhenping 程震平, and he may have written or copied all the books. The handmade paper in most of these volumes is of poor quality, made of bamboo with straw mixed in. The calligraphy also indicates a person(s) with limited formal education or practice in calligraphy. I bought the set at the Hangzhou Collected Treasures Market [Shoucangpin shichang 收藏品市 場] in June 2014. The dealer who sold it to me was from Wanhuangshan 皖黃山, Yin 歌 County, Anhui 安徽 Province, and he told me this collection was from Huizhou 徽 州.

Ancient Texts Explained [Guwen shiyi 古文釋義] is a hand-copied work intended to be used as a textbook for high school or university-level students studying model essays on historical persons and episodes. It is $9-5 / 8$ inches $(24.33 \mathrm{~cm}) \mathrm{h} \times 5$ inches $(12.7 \mathrm{~cm}) \mathrm{w}$, a good size for a study manual. It has fifty-nine pages plus a front and back cover with text and was purchased in Beijing in September 2005. Its contents are 144 selections of prose from the Qin 秦 (221-206 BCE) through the Ming 明(1368-1644CE) dynasties. The woodblock edition of this collection was originally published in 1743. My handwritten copy is titled vol. 5 , and the specific date of copying is given: "This book was copied on February 31, 19oo, and is listed as vol. 5, Containing Twenty-Two Essays" [Guangxu ershiliunian eryue sanshirizhi.Jiwuxueshu gongji ershierpian 光緒二十六年二月三十日 止. 輯五學書共計二十二篇]. Among the essays in my manuscript copy is "A Record of One's Emotions” [Chenqingbiao 陳情表], by the Jin official Li Mi 李密 (224-287 CE). The essay discusses the rise of a person of humble birth to high office. Chapter 2 also

(C) RONALD SULESKI, 2018 | DOI:10.1163/9789004361034_013

This is an open access chapter distributed under the terms of the prevailing CC-BY-NC License at the time of publication. 
comments on the interesting story written on the inside of the back cover, a story probably then circulating among students around 1900, and the response written by another student on the outside back cover. Those items were not part of the standard collection of works included under this title.

Astrologer's Predictions 1899 (no clear title in Chinese). This colorful and illustrated handwritten horoscope was prepared for an infant whose guardians were concerned about his future. The subject of this horoscope was born in 1898. An August and Accurate Chart of Fate [Ziwei mingpan 紫薇命盤] appears on pp. 2 and 3, graphically illustrating the fate of the person whose future was being calculated. The circle was constructed of five concentric rings, meant to be read from the center of the circle outward, following one of the "spokes" in the circle. The following pages contain predictions for each year from 1899 to $195^{2}$, using many references to water and water transport. Because of the references to water and the place name Wenzhou that appears in the text, I have assumed this was written for a person living in the Wenzhou area. It is $9^{1 / 2}$ inches $(24.1 \mathrm{~cm}) \mathrm{h} \times 5^{1 / 4}$ inches $(23.5 \mathrm{~cm}) \mathrm{w}$ and has twenty-two pages. I bought it the Confucian Temple Sunday Market in Shanghai in January 2012.

Basic Primer [ Gyemongpyon 계몽편 啟蒙篇]. A hand-copied textbook intended to introduce Chinese classical learning to Korean students, it was produced in Korea for Korean students. The chaoben opens with the classic text Lunheng 論衡 [Balanced Inquiries], by Wang Chong 王充 (27-100 CE?), beginning with "Above is heaven, and below is earth. Between heaven and earth lives man" [Shang youtian, xia youdi. Tiandi zhijian you renyan 上有天, 下有地. 天地之間有人焉]. It might be from the late Choson 朝鮮 period $\left(1895^{-1910}\right)$ of Korea. This booklet has grammatical phrases added to the Chinese wenyanwen 文言文 text in hangul 한글 so that Korean students can understand the phrases written in Chinese characters. The markers were hangul phrases, such as hago 하고 [and]; ira 이라 [a sentence ending], so that it would sound more like a Koreanlanguage work. The handmade paper was bleached and is thicker than most handmade Chinese paper of the era. It is $9^{1 / 2}$ inches $(24.13 \mathrm{~cm}) \mathrm{h} \times 8$ inches $(20.32 \mathrm{~cm}) \mathrm{w}$, a shape that looks more square than oblong, whereas most Korean books are square. I bought the twenty-four-page chaoben in Seoul in September 2005.

Cao Suosen 曹鎖森 is a name written on the cover. This book is a list of incantations to deal with illnesses and other human afflictions, many of which are accompanied by a talisman character [符 $f u$ ] that will mobilize the deities to help the afflicted. It is written in a quite passable hand. The Celestial Lord Who Relieves Suffering [Taiyi juiku tianzun 太乙救苦天尊] is on p. 11. This deity is usually associated with death, because he descends to Hell to search for and free tortured souls. See p. 18 for summoning General Ding 丁將軍 [Ding jiangjun], and p. 19 for summoning 
General Heng [Heng jiangjun 衡將軍]. They are spirit generals [shenjiang 神將] who can command their ghostly soldiers [yinbing 陰兵] to defeat evil and troublesome [sha 憊] forces. Snakes [she 蛇] are talked about on pp. 21-26, viewing the snake as a frequently curative agent. Talisman are drawn on various pages. It is 9 inches $(22.86 \mathrm{~cm})$ $\mathrm{h} \times 5$ inches $(12.7 \mathrm{~cm}) \mathrm{w}$, has seventy-seven pages, and was purchased in Shanghai in 2014.

Ceremonies [Liben 禮本] is a handwritten booklet listing in some detail the various protocols and ceremonies to be followed, especially in a Chinese wedding that will follow traditional practices. It was written by Wu Shubi 吳書壁, probably in 1945 . Newlyweds stopping before the stove god is explained on p. 14; the stove god (or the god of the kitchen) is seen to represent the bonds and actions that tie a family together. This was a brave attempt to preserve and continue the complex and established wedding rituals in 1945, at a time when the war with Japan had ended or was about to end, and the Chinese Civil War between the Nationalists and the Communists was about to begin in earnest. It is $7^{1 / 4}$ inches $(18.41 \mathrm{~cm}) \mathrm{h} \times 5^{1 / 2}$ inches $(13.97 \mathrm{~cm}) \mathrm{w}$ and has seventy pages. I bought it in Beijing in January 2015 .

Celebrations Pawnshop [Qingjidang 慶記當]. This shop was headquartered in Changchun 長春 in the 1920s. Its owner was registered as Luo Ruitang 羅銳棠, and it was located on the main road [Big Horse Road; Dama lu 大碼路]. In the two volumes in my collection is vol. 1 from January 1928, which has a tax stamp issued by authorities in the Republic of China [Zhonghua minguo 中華民國] and vol. 2 from January 1945 as it continued to operate when the region was occupied by Japan and Changchun was the capital of Manchukuo [Manzhouguo 滿洲國], recording its accounts in national currency [guobi 國幣]. Customers were each assigned a coded designation, such as $j i$ [吉; vol. 1, p. 36], or zao [造; vol. 2, p. 46]. Vol. 1 from 1928 is $83 / 4$ in $(22.21 \mathrm{~cm}) \mathrm{h} \times 7^{1 / 4}$ in $(18.42 \mathrm{~cm}) \mathrm{w}$ and has seventy-six pages. Vol. 2 from 1945 is $81 / 2$ in $(21.59 \mathrm{~cm}) \mathrm{h} \times 6 \frac{3 / 4}{4}$ in $(17.12 \mathrm{~cm}) \mathrm{w}$ and has 196 pages. Vol. 2 lists the year as Kangde 12 [Kangde shier 康 德拾貮], referring to the reign of Manchukuo's puppet emperor Puyi 溥儀. Kangde 12 was 1945, and it appears this volume was completed at the end of 1944, perhaps by the lunar calendar, but the year designation of 1945 adopted by the Japanese was written on the cover because the Japanese followed the Western calendar. I bought them in Changchun in December 2012.

Ceremonies for the Dragon Kings [Longwang fashi 龍王法事] is concerned with many Buddhist dragon kings. It explains how to approach them by preparing memorials [zou 奏] and official requests [ $\mathrm{die}$ 牒] that are then ceremoniously presented to ask for their help. It is dated renyin nian 王寅年, that is, 1902, and has thirty-four pages of handwritten text, which tend to refer to the dragon kings by their Buddhist (Sanskrit) names. In 
Hindu thought, many dragon kings often took the shape of a snake; this concept carried over into Buddhist thought, which postulated many dragon kings and was also appreciated by the Chinese Daoists for its symbolism. Dragon kings have a dual personality because they can bring nourishing rains or wreak havoc through powerful floods. It is $9 \mathrm{in}(22.86 \mathrm{~cm}) \mathrm{h} \times 5^{1 / 4}$ in $(13.33 \mathrm{~cm}) \mathrm{w}$ and was purchased in January 2010 in Beijing.

Chants of Repentance to the Three Primes [Sanyuan fa chan 三元法懺]. These are prayers, petitions, and confessions to ask for help and forgiveness from the Three Officials [Sanguan 三官] honored by Daoists. This fifty-one-page chaoben is used as a ritual text [keyiben 科儀本] for the popular Daoist (and Buddhist) practice of reciting chants [chan 懺] to atone for past transgressions. On the second to last page (p. 49), the copyist gives his name as Wang Shuxiang 王恕鄉 and tells us he copied the book in 1909, in the second month of the first year of the Xuantong era [Xuantong jiyou yuannian eryuezhong wangerri chaocheng 宣統已酉元年二月中望二日抄成]. On the last page (p. 51), the copyist used a brush to pen "Recorded by Wang Shoudao" [Wang Shoudao $j i$ 王守道記]. This is likely to be the religious or temple name of the copyist, since the name means to "Protect the Dao." However, on the first page of the book and at many points throughout the text, “Copied by Wang Youda” [Wang Youda ji王有達記] is stamped in black ink. We can assume that these are all names of the same copyist. The many personal seals placed throughout the text indicate that he was an active ritual specialist and certainly was proud of his work. The book is $9^{1 / 4}$ in $(25.46 \mathrm{~cm}) \mathrm{h} \times 5^{1 / 2}$ in $(13.97 \mathrm{~cm})$ w. I bought it in Beijing in January 2008.

Characters for Elementary Education [Zhengmeng ziyi 正蒙字義]. This is a woodblock printed dictionary that goes well beyond what would have been considered an appropriate level for elementary education. It would have been a useful reference dictionary for a student preparing for a government examination and the degree to be awarded under the traditional system. The title was brushed in, but the printed title on each woodblock sheet says Zi yi 字義 [The Meaning of Characters]. Part 1 [shangpian 上篇] is fifty-one folio leaves, and part 2 [xiapian 下篇] is thirty-plus folio leaves. The very pliant quality of the bleached paper and the sharp printing indicate this quality volume is most likely from the late Qing period. My copy does not have any publishing information on it, but a woodblock edition of this title was published in 1901 by the Chongqing Zhengmeng Academy [Chongqing Zhengmeng gongshu 重慶正蒙公塾]. The woodblock edition appears from records to have had reprints of famous "Family Instructions" [ jiaxun 家訓]. It is $9^{1 / 2}$ in $(24.13 \mathrm{~cm}) \mathrm{h} \times 6$ in $(15.24 \mathrm{~cm}) \mathrm{w}$, and I bought it in Shanghai in January 2013.

Collected Scripture of the Deeds of the Jade Emperor [Gaoshang Yuhuang benxing jijing 高上玉皇本行集經], with an additional short text of six pages titled "Scripture of 
Repentance" [Chanhuijing 懺悔經]. This is a hand-copied collection of prayers and text honoring the Jade Emperor, based on one of the standard canonical texts recognized by Daoists. Vol. 1 [shang 上] has forty-five leaves; vol. 2 [zhong 中] has thirty-eight leaves; and vol. 3 [xia 下] has forty-one leaves. The entire handwritten version is in three twine-bound volumes on bleached handmade paper and was written in a practiced and attractive though not elegant hand. On the cover page of each volume, the place of copying is given as the Hall of Profound Virtue [Houdetang 厚德堂]. The total of 124 leaves (folded pages), or 248 individual pages, was lovingly written by Gu Yitang 顧義堂 (which may have been his "religious" or "ordination name") in the spring of 1879 . The cover of each volume is stamped with a large seal that says "The Three Treasures of the Dao, the Scriptures, our Teachers" [Daojing shi bao 道經師寶]. Much good karma must have accrued to $\mathrm{Mr}$. Gu. It is $9^{1 / 2}$ inches $(24.13 \mathrm{~cm}) \mathrm{h} \times 5$ in $(12.7 \mathrm{~cm}) \mathrm{w}$. I bought this in Shanghai in 2010.

Congratulatory Phrases for the Household [Jiayong zhuci 家用祝詞]. This 112-page handwritten book is filled with all sorts of sample letters, matching couplets, family announcements, and so forth, covering all typical family transitions. What appear to be sample letters in some damaged pages are followed by announcements concerning funerals and to have the elder's son or the grandson take charge of the ceremony and the reading of the eulogy, on pages eight to sixteen. Various sample contracts for selling land or manipulating the size of plots, etc. are on pp. 28-48. Other topics covered are marriage [xinhun 新婚] on pp. 62-71, and congratulatory phrases for the birthdays of elders [shou dan 壽誕] on pp. 72-78. Matching couplets for the deities of popular religion are on pp. 79-91. Two addresses to deliver at a ceremony honoring students who are graduating on pp. 98-101. On this last page is the date of the Tenth Year of the Republic [Zhonghua minguo shinian suici 中華民國十年歲次], which is 1921. This book is 9 inches $(22.86 \mathrm{~cm}) \mathrm{h} \times 5^{-7} / 8$ inches $(14.68 \mathrm{~cm})$ w. I bought it in Hangzhou in May 2012.

Criminal Inquest [Salokjueinchang 살옥죄인장/殺獄罪人狀] has this title because of one of the items that immediately caught my attention. The books were written in classical Chinese, as was the custom for educated Koreans when using a brush in the 18oos. In vol. 1 on pp. 26 and 27, the writer copied the text of a legal document titled "Criminal Case of Death of the Defendant in Kwangju, Fourth Reading" [Kwangju salok jueinchang, sajae 광주살옥죄인장사제/廣州殺獄罪人狀四題]. This was an adjudication, the fourth one, rendered by a provincial governor after reviewing an inquest report compiled by a country magistrate from the county where the drowning death of Yi Tong-ae 이동애/李東崖 took place. It appears that Mr. Yi was stressed out because of the demands of creditors who wanted him to repay his debts, and because of his wife's persistent nagging. The couple got into a fight near a river, throwing sand at 
each other, and Tong-ae was acting in a crazed manner. Somehow, by accident, the couple fell into the river and drowned. The court found that Mr. Son 손/孫, perhaps the creditor who had been constantly dunning the Yis to repay what they owed him, was not guilty of killing Mr. Yi, but he was punished with one round of beating because his constant pressure had caused Yi to become irrational. I assume this incident took place around 1879 . Vol. 1 , containing the criminal inquest, is 10 inches $(25.4 \mathrm{~cm}) \mathrm{h} \times 5^{3 / 4}$ inches $(14.61 \mathrm{~cm}) \mathrm{w}$ and has thirty pages. Vol. 2 is 12 inches $(30.48 \mathrm{~cm}) \mathrm{h} \times 6 \frac{1}{2}$ inches $\left(16.5^{1 \mathrm{~cm}}\right)$ and has twenty-four pages.

Domestic Gold and Silver [neizaojinyinsu 內造金銀素]. This chaoben has lost its cover so I have no information about its name or location or the date of the document. I assigned it this title based on the first words of the extant text. It is from a trading company that dealt in woven products of cotton, brocade, and wool. It also sold animal skins and furs for clothing. In addition, it was a dealer of precious stones used for jewelry and ornamentation. The company listed the products it offered for sale, which had been acquired from all over China as well as from abroad. The first section, cloth and woven products, is on pp. 1-17. Each item is described by the point of origin of the product and the lengths in which it was available. The second section, animal skins [pi lei 皮類], is on pp. 17-19. The third section is precious stones [baoshi lei 寶石類], on pp. 30-43. This section includes a discussion of how to distinguish precious stones from less valuable stones and how to determine their market value. The geographic place and references used mark this chaoben as being from the Qing era. Among those place names are Shuntian fu 順天府 (p. 10), Korea [Chaoxian guo 朝鮮國; p. 10], Huguang 湖廣 (p. 13), Gaoli 高麗 (p. 17), Fengtian $f u$ 奉天府 (p. 21). The book is $10^{1 / 2}$ inches $(26.67 \mathrm{~cm}) \mathrm{h} \times 81 / 4$ inches $(20.96 \mathrm{~cm}) \mathrm{w}$. The paper used, which is as thin as cloth with many imperfections, dates it to the mid-Qing; however, considering the wide areas from which the products came, it might be from the late Qing and could have been based in almost any part of the country. The forty-three-page chaoben was bought in Beijing in 2012.

Eight Effective Formulas [Ba qinkoujue 八親口決]. The final character 決 [jue] should probably have been written 訣. This is a handwritten collection of incantations addressed to the Eight Evil Great Generals [Basha dajiangjun 八憊大將軍]. Because they are so powerful and frightening, the text also includes many magic talisman [ $f u$ 符] that can be used to command and control the generals. These talisman contain many characters and make good use of calling upon the thunder god [Leigong 雷公] to keep the spirit generals under control. It calls upon the Spirit Generals and their troops and horses for help in dealing with unwanted ghosts [gui 鬼] and evil forces [sha 憊]. The generals themselves are evil but can be commanded to suppress the evil forces. This is a representative portion: 
The spirit soldiers with horses, go under the bridge; soldiers without horses, march under the bridge. Soldiers who arrive at the altar, remove your armor. As horses arrive at the altar, take off their saddles. At this time your follower will burn incense to ask a thousand soldiers and ten thousand horses to attend the altar.

You ma shenbing, qiaoxia guo; wuma shenbing, qiaoxia xing. Bing daotanqian, xiexia jia. Ma dao tanqian, xiexia an. Jinshi, dizi fenxiang, qing qianbing wanma, futanting.

有馬神兵, 橋下過; 無馬神兵, 橋下行。兵到壇前, 卸下甲。馬到壇前, 卸下鞍。今時弟子焚香, 請千兵萬馬, 赴壇庭。

p. 19

Drawings of some sha forces are on pp. 47-52, with talismanic characters dealing with sha on pp. $43^{-46}$. This fifty-three-page text is $9^{3 / 4}$ inches $(24.76 \mathrm{~cm}) \times 6 \frac{1}{4}$ inches $(15.87 \mathrm{~cm})$ w. It was written and illustrated in October 1904, and I bought in Beijing in January 2015 .

Eulogies [Mansa 만사/輓詞]. The front and back covers are missing from this fifty-fivepage handwritten manuscript bound in twine. It is a lengthy and detailed commentary on the proper way to hold a funeral and burial. The text contains two funeral orations [chaemun 제문/祭文], which appear to be eulogies written by the author of the text or by a relative but copied into this text. These have useful information to help us place the entire manuscript in the context of its location and the family described. The book is $93 / 4$ inches $(24.76 \mathrm{~cm}) \mathrm{h} \times 9-7 / 8$ inches $(25.02 \mathrm{~cm}) \mathrm{w}$, giving it an almost square shape, which was uncommon in Chinese chaoben. I bought it at the Sŭngmun'gak 승문각/承 文閣 in Insadong 인사동/仁寺洞, Seoul in December 2010.

Exchanging Conventional Greetings [Hanwon ch'arok 한훤차록/寒暄劄錄], a guide about how to properly address government documents, letters, and official reports. The text was compiled in 16o6, but this woodblock reprint appears to be latter Yi Choson 이조선/李朝鮮 (i.e., 180os). It is $10^{3 / 4}$ inches $(27.3 \mathrm{~cm}) \mathrm{h} \mathrm{x} 7^{1 / 2}$ inches $(19.05 \mathrm{~cm}) \mathrm{w}$, and was purchased in Seoul in December 2010.

Family Registry [ Jiabu 家簿]. This is a seven-page handwritten family history that was written in 1742 during the reign of the Qianlong emperor $\left(1735^{-1796)}\right.$. It was prepared by Zhao Xing 趙星 from Quwo 曲沃 County in Shanxi 山西 Province. He has basic listings for five past generations, but for his father's generation (generation number six) and his own (generation number seven), he lists several uncles (along with the surname of their wives and the number and sex of their children), and he lists his 
three brothers along with their wives and children. Zhao Xing and his three brothers had single-character [danming 單名] given names, but each name had a "sun" [ ri 日] element. His brothers were named Min 旻, Yu 昱, and Jing 景, and he was named Xing 星. The large size of the pages indicates this may have been a family of some standing that showed its social status by producing the genealogy in this oversize format. Chun Shum 沈津, while the rare book librarian at the Harvard-Yenching Library, confirmed that the bark-fiber paper appeared to date from the Qianlong era. This work, bound in twine, is $15^{1 / 2}$ inches $(39.4 \mathrm{~cm}) \mathrm{h} \times 10$ inches $(25.4 \mathrm{~cm}) \mathrm{w}$ and was purchased in Beijing in April 2009.

Fifty Days to Encounter the Five Spirits [Wushi zhiri feng wudao 五十之日逢五道]. This is an example of written material that might be used by a yinyang master [ yinyangshi 陰陽師] or an exorcist. It contains a sixty-day cycle (actually here a fifty-day cycle) explaining the goblin that might cause physical distress on each particular day. It gives the name of the noxious spirit, the kinds of physical ailments it will cause, and the location in or near the household where it hides. This is clearly not an elegant work but one meant to be used by a person not of high social standing. The paper is of bamboo with some straw mixed in, but it is smooth and soft and so can be considered good paper. Bought in December 2012 at Beijing's Panjiayuan market, this nineteen-page handwritten chaoben is $7^{1 / 4}$ inches $(18.41 \mathrm{~cm}) \mathrm{h} \times 5$ inches $(12.7 \mathrm{~cm}) \mathrm{w}$ and bound with twine.

Fortunes [Ming 命]. This 196-page account was written with a fountain pen and then a ballpoint pen, covering the period from the 1950s through the 1970s. It appears the fortuneteller used these pages to calculate the fate of the people who came to ask his advice and to write down his prediction about their fate. The book is $93 / 4$ inches $(24.76)$ $\mathrm{h} \times 63 / 4$ inches $(17.15 \mathrm{~cm})$ w. I purchased it in Harbin 哈爾濱 in June 2011.

Funeral Orations [Jiwen 祭文]. The cover page has fallen away from this book, so it has no title. Funeral orations were eulogies that were read out at funerals, before the ancestral altar or in front of the grave at memorial services. They usually are from the point of view of the "unfilial son" [buxiaozi 不孝子] and recall the hard work and self-sacrifice of the departed, usually a parent, whose life is being memorialized. Sometimes, when the reader recalls memories of past events from earlier days, the text becomes quite personal. It likely dates from the early Republic, because the text contains the phrase Great Han Republic [Dahan minguo 大漢民國, which later became the standard Zhonghua minguo 中華民國]. Among the smaller number of handwritten chaoben that I found at Korean markets, composing eulogies for departed relatives seems to have been considered an important part of honoring the departed, and they seem to be more common in Korea than in China. The funeral orations are on pp. $5^{-}$ 19, followed by a poetic rhyming section on pp. 21-54, based on the Kangxi Dictionary 
[Kangxi zidian 康熙字典]. It is not unusual to find a chaoben with information on several subjects within its pages because chaoben like this one can be seen as reference notebooks used by the person who wrote out the text. This chaoben is $7^{1 / 2}$ inches $(18.41 \mathrm{~cm}) \mathrm{h} \times 4^{1 / 4}$ inches $(10.79 \mathrm{~cm}) \mathrm{w}$, and I bought it in Guilin in September 2005 .

The Golden Bough [Dajinzhi 大金枝]. This story that has several names, the more common ones being "Striking the Golden Bough" (Dajinzhi 打金枝, which has the same pronunciation as written in the chaoben in my collection but uses a different character), and "Striking the Golden Bough While Drunk" [Zui dajinzhi 醉打金枝]. It is a wellknown story based on actual historical figures. Guo Ai 郭曖 $\left(725^{-800}\right)$ was the sixth son of the well-respected General Guo Ziyi 郭子儀 $(697-781)$. In the year 765 the thirteenyear-old Guo Ai was married to the Princess Royal Shengping [Shengping gongzhu 升 平公主], who was similar to him in age. They had a passionate relationship in both their intimate relations and in their quarrels. The story has been made into traditional operas of all types, as well as into stage plays, movies, and television dramas. The text in my collection tells the story with dialogue and singing. It also has stage directions for all of the opera performers written throughout. The book of forty pages is $8 \frac{1}{2}$ inches $(21.59 \mathrm{~cm}) \mathrm{h} \times 7^{1 / 4}$ inches $(18.38 \mathrm{~cm})$. My colleagues suggested this was from a southernstyle opera [yueju 越劇] version. Inside on p. 22 is the name Zhang Jishan 張繼善, which might have been that of the owner of the manuscript, the copyist, or one of the performers who thought of himself as notable. It was purchased in Hangzhou in June 2012.

Household Almanac [Jujia biyong 居家必用]. This is a handwritten almanac intended for people in Gaomi County, Shandong Province, based on an address written on the last page (p. 155): Great Qing, Shandong Laizhou fu, Gaomi xian, Zemin xiang, Dianxi she, Immortal Li Village [Da Qingguo, Shandong, Laizhoufu, Gaomixian, Zeminxiang, Dianxishe, Lixianzhuang 大清國, 山東, 萊州府, 高密縣, 澤民鄉, 店西社, 李 仙庒]. The Gaomi County designation also appears on pp. 20 and 74 . This is a quick compendium of things a farmer might need to know, such as how to write numbers in the traditional or complex style, or as so-called Suzhou numbers [Suzhou mazi 蘇州 碼子] based on an ancient rod system that was once popular in Chinese marketplaces and used by merchants or for commercial purposes. It also gives the major crops grown, information about the growing season, a glossary of many words for items of everyday use, types of dwellings, medicines, the deities worshiped, and so on. It also describes ghosts that can afflict a person, calculated for a thirty-day period. This lists the ghosts by day, surname of ghost, and location in the home where the ghost can be found sitting. This section of the manuscript (pp. 139-150) is titled "List of Sick Days" [Fabingshu 法 病書]. The date this was copied is given as 1935 (p. 155), but the original date of the 
manuscript dates from the Qing dynasty. The book is $7^{3 / 4}$ inches $(19.68 \mathrm{~cm}) \mathrm{h} \times 5$ inches $(12.7 \mathrm{~cm})$ w. I bought this 155-page chaoben in Beijing in June 2010.

How to Cure Illness [Bing zhi fang 病治方]. A woodblock printed text of sixty-eight highly illustrated pages written (based on the name stamps inside) by Hao Liugui 郝留 桂. This looks like a Qing-era work. Can animals be responsible for certain emotional and mental irregularities? The illustrations in this booklet sometimes show a person curled in a fetal position, with the drawing of a scary insect above them and a brief explanation of the presenting symptoms on the page. The small book is 6 inches $(15.24 \mathrm{~cm}) \mathrm{h} \times 4^{1 / 4}$ inches $(10.79 \mathrm{~cm})$ w. It was purchased in Beijing in 2013.

An Illustrated List of Common Words [Huitu suyan zazi 繪圖俗言雜字]. This is a zazi intended primarily to teach how to write characters that could be used for self-study. Each page has illustrations of clothing, goods for daily use, utensils, and items for religious occasions. The student who rebound the book in 1941 wrote its title as "List of Common Agricultural Terms" [Sunong zazi 俗農雜字, a title in common use], with his name: Liu Weisheng 劉衛生. This book of nineteen folio leaves is 8 inches $(20.32 \mathrm{~cm})$ $\mathrm{h} \times 5^{1 / 4}$ inches $(13.34 \mathrm{~cm})$ w. It was printed in Andong 安東, Manchukuo, in 1936 .

Illustrated Precious Jade Calendar to Save the World [Huitu Yuli baochao quanshiwen 繪圖玉暦寶鈔勸世文] (Shanghai: Jinzhang tushuju, 1921?). This publication has appeared in China for decades. It contains stories of people who have turned to the deities for help with sincerity and have been rewarded with good fortune. The stories seem to be drawn from real life and are updated in the various published editions, so that, whereas the version listed here gives stories from the Qing through the early Republic, modern versions currently available in China have stories that took place in the 1920s, the 1970s, and so on. This book is treated as a "precious book" [shanshu善書] and is reprinted by many temples in China and given away free. The book also has an illustrated section portraying the netherworld of Hell to which sinners are condemned to suffer. In this edition, the illustrations are on pp. 7-18. This is a printed edition. The book is $81 / 2$ inches $(21.21 \mathrm{~cm}) \mathrm{h} \times 5^{3 / 4}$ inches $(14.61 \mathrm{~cm}) \mathrm{w}$. I bought it in Beijing in June 2013.

Incantations to Send Off Ghosts [Songgui chongzhou 送鬼崇咒]. This title has 112 pages (including partial pages) and is dated 1887. It was copied by Qu Runtian [Qu Runtian $j i$ 曲潤田記; cover, p. 1]. All the days in a sixty-day cycle of each of the heavenly stems and earthly branches are listed, including the symptoms of the afflicted person and the benevolent spirits that can be called upon for help. The book is $7 \frac{3 / 4}{4}$ inches $(19.68 \mathrm{~cm}) \mathrm{h} \times 6$ inches $(15.24 \mathrm{~cm}) \mathrm{w}$. I bought it in Beijing in June 2014. 
Internal and External Medical Complaints [Neiwaike yanke zazheng 內外科眼科雜 症]. Diseases of the eye, or oracular medicine, is also included in the title [yanke 眼 科]. This seems to be the collected writings and notes of Dr. He Jinliang 何錦樑, who practiced in Shanghai in the 1930s and 1940s. He was an herbal doctor. Based on these collected writings, he also seemed to have been a practicing Daoist ritual specialist. In the text, he turns from copying down prescriptions for various medical afflictions to suggesting some Daoist rituals to remove noxious forces. Moreover, he was possibly a landlord who collected rent from tenants west of Shanghai. It is possible Dr. He owned some properties [called zhuang 庒] near Hangzhou, but confirmation of this awaits more research. Instead of properties, might these have been small pharmacies? Or was zhuang a code word for people who owed him money?

It seems as if at some point he took a lot of his writings on varying sizes of paper and bound them together. It is equally possible that his students bound them together after Dr. He's death. Some differing calligraphic styles are evident in this collection, which measures 8 inches $(20.32 \mathrm{~cm}) \mathrm{h} \times 5^{1 / 4}$ inches $(13.33 \mathrm{~cm})$ w. Tucked inside the pages was a small pamphlet of common medical terms and their manifestations, titled "Popular Medical Advisor" [Minzhong yiyao guwen 民眾醫藥顧問]. It was distributed free by the Shanghai United Friendship Society [Shanghai lianyishe 上海聯誼社] and is dated 1945. This eleven-page pamphlet is $5^{3 / 4}$ inches $(14.61 \mathrm{~cm}) \mathrm{h} \times 3^{1 / 4}$ inches $(8.26 \mathrm{~cm}) \mathrm{w}$. I bought Dr. He's writings in Hangzhou in May 2012.

Invitations and Matching Couplets [Tieshi duilian 帖式對聯]. This handwritten text could be used as a practical reference work on how to word invitations and social notices politely in a rather stylized, perhaps even then outdated manner, and it also contains sample texts of various matching couplets [duilian 對聯] to be used on celebratory occasions. The chaoben is dated 1907. Its sample texts distinguish all categories of relationships, each calling for the use of a particular relationship term. This is one of the chaoben I bought in South China that has covers (endpapers) of a red-orange color. This type of paper was used from the Ming and Qing dynasties in Guangdong 廣東 and other southern provinces. It was treated with insecticide, a mixture consisting of read lead [hongdan 紅丹], sulfur, and saltpeter. Its bright color was called "Ever Red" [wannianhong 萬年紅]. It was toxic to bookworms and was meant to protect the inside pages of the book. Indeed, the pages of this book do not show the typical holes made by worms or insects typically found in old chaoben. The stamp of the owner Dong Gongda 董恭達 is on various pages in accountant's ink, which was blue or purple. The basic quality of the paper, made from bamboo, is good. The discoloration around the edges of the pages was caused by an oily substance, but the paper remains strong and intact nonetheless. It has 114 pages and measures $5^{1 / 2}$ inches $(13.97 \mathrm{~cm}) \mathrm{h} \times 5^{-7} / 8$ inches $(14.73 \mathrm{~cm})$ w. I bought it in Guilin in September 2005 . 
Items for Mourning [Ch'osang ch'egu초상제구初坒諸具]. This handwritten book from Korea of seventy-six pages devotes most of its text to funeral and mourning rituals. On page 67 , the author includes a chart of all the Yi Choson kings, ending with the "current" [kŭmsang 금상/今上] King Ch'ŏljong 철종/哲宗, who reigned from 1849 to 1863. By listing him as the current king, we know this text was written before 1863 . Perhaps this was a type of "subversive" text that would have been dangerous if found by certain factional leaders, and so its author hid its observations of political party factionalism within a book about funeral arrangements? The paper is made from white mulberry (referring to the category of the plant, but not its color). It is pure white mulberry bark paper. Paper made from bark is thicker and sturdier than other types of handmade paper. A sieve with a wide woven pattern was used in making it. After the Song dynasty, in general the Chinese produced less paper using mulberry bark, preferring less expensive materials, such as rice or bamboo. The book is $7^{3 / 4}$ inches $(19.68 \mathrm{~cm}) \mathrm{h} \times 5^{1 / 4}$ inches $(13.34 \mathrm{~cm}) \mathrm{w}$. I bought it in Seoul in September 2005.

Land Contracts of the Tang 湯 Family of Hanyang [Hanyang Tang-shi diqiji 漢陽 湯氏地契集]. Their property was located in Hubei 湖北 Province, Hanyang 漢陽 $f u$, Huangpi 黃皮 xian, Xi 西 xiang, near the Tianjing 天井 temple. The handwritten land contracts in my collection date from 1775 to 1948 , and the names of the contract writers, guarantors, and witnesses will allow, among other information, the reconstruction of the male members of the clan over that 173 -year period of time. This collection contains over thirty handwritten land contracts, some tax receipts, and three requests to a Daoist temple for religious services on behalf of a family member. I acquired this collection in Shanghai in 2008.

Land Documents [Densho meitsuki shōmon Mukai 田所名附證文向]. These are handwritten records from Japan that describe the sale, transfer, and disposition of land. The lands referred to in this collection were located in Echigo 越後, an area on the central [chübu 中部] and western side of the main Japanese island of Honshū 本州, roughly equivalent to the present-day prefecture of Niigata 新潟. The specific address, as written on p. 79, was Echigo, Koshi-gun, Takanami-hiro [越後古志郡高浪 [広?]. The records

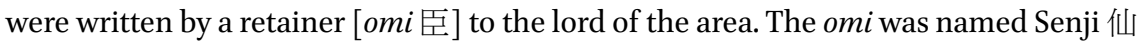
児. His seal appears below his name on page 79, which lists him by his correct title as "Retainer" [Shinshi 臣子]. This collection was prepared in 1849. The book is $10^{3 / 4}$ inches $(27.31 \mathrm{~cm}) \mathrm{h} \times 9^{3} / 4$ inches $(24.76 \mathrm{~cm})$ w. I bought it in Tokyo in 1995 .

A List of Characters to Teach the People (Shenqun shunzi 申群順字). This is a vocabulary list ( $z a z i$ 雜字) intended primarily to teach written characters. It could be used without a teacher for self-study. This work of twenty-four pages was purchased in Beijing in January 2008. It is $6 \% 3$ inches $(17.14 \mathrm{~cm}) \mathrm{h} \times 4$ inches $(10.16 \mathrm{~cm}) \mathrm{w}$. This is a handy 
"pocket" size. The title page contains the words, "Written on 12 June 1930 (in the intercalary month of June), in the summer." In the student's poor calligraphy is written the inspirational phrase "The Mountains are High and the Rivers Long." (Minguo shijiunian runliuyue shi'errixiali. Shangao shuichang 民國拾㺵年閏六月十二日夏立. 山高水 長, page one.) The text follows ideas of conventional morality: "Respect heaven and honor the earth, Honor your ancestors and make offerings to the gods; Be obedient to your parents, Increase your children and grandchildren," (Jingtian lidi, jizu sizong; Xiaoshun fumu, fada zisun 敬天禮地, 祭祖祀宗; 孝順父母, 發達子孫, pages twentytwo and twenty-three). Some scholars have suggested this item could be titled "Words (Written) by Shen Qunshun." That is because the first three characters form a commonly used name and the complete title still would read the same as I have given for this chaoben. On the first page it gives its title as "Four Word Vocabulary List" [siyan zazi 四言雜字], which although a generic title, can be taken as its title. In that case the title I have given above would read “Written by Shen Chunshun” [Shen Qunshun $z i$ 申群順 字].

Liu Fengge 劉鳳閣 [Liu Phoenix Hall, or the name of the author of this text]. This name is stamped on the cover of both volumes in purple ink. This is a handwritten text about how to prepare woodblocks in terms of the calligraphy of the wood measurements and carving text into it. It appears to have been written in late 1936, with notes and the date of January 1937 added. The earlier date Kangde 康德 3 (1936) refers to the Manchukuo 滿 洲國 period. Vol. 1 is thirty-two pages, using lightweight, probably machine-made paper. Vol. 2 has forty-six pages. Each volume is 8 inches $\left(20.3^{2} \mathrm{~cm}\right) \mathrm{h} \times 5^{1 / 4}$ inches $(13.34 \mathrm{~cm})$ w, purchased in Harbin in January 2013.

Ma Family Land Contracts [Mashi diqi 馬氏地契]. This is a bound collection of land contracts (deeds). The Ma family property was in Hebei 河北 Province and was referred to as "our village" [jiangcun 將村, a phrase that appears in most of these contracts; p. 15]. Twenty contracts are bound together covering 1879 to 1943. They are all white deeds with no seals of any kind, though it is clear the Ma family played a central role in writing and verifying each deed, including measuring the land [guanchi 官尺] to be rented or sold. The cover pages had blue accountant's cloth pasted over them, as was typical in commercial ledgers. The collection is $10^{1 / 2}$ inches $(26.67 \mathrm{~cm}) \mathrm{h} \times 9^{-}-7 / 8$ inches $(25.02 \mathrm{~cm})$ w. It has forty pages and was purchased in Beijing in June 2013.

Ma Jiwu 馬䮑伍. This is a collection of observations on life. It is an eighty-eightpage handwritten collection produced in 1924. Mr. Ma. He appears to have lived in Manchuria. Among other topics, he wrote about sexual activity at the time and the intersection of sex and money. He was studying Japanese (pp. 6o-82). In 1927 another person acquired this work and wrote that Mr. Ma had moved to Lanzhou 蘭州, Gansu 
甘肅 Province, to become an official. “The official appointment took away his free time” [Guan ranshizhi suishibian 官任事止隨時變; p. 86]. The book is 7-7/8 inches (19.94 cm) $\mathrm{h} \times 5^{1 / 2}$ inches $(13.97 \mathrm{~cm})$ w. I bought it in Beijing in May 2010 .

Mr. Bai's Notebook [Bai xiansheng zhi chaoben 白先生之抄本]. The booklet had no title, so I named its author Mr. Bai [Baixiansheng 白先生]. This chaoben is filled with some standard poetry, with an essay, but the majority of items are sample texts for matching couplets divided into categories. This was a working text, often consulted, with new information added at various points. It is a good example of the notebook kept by a xiucai 秀才 scholar in the course of his business dealings, which were based on the scholar's ability to read and write, earning income as he catered to the needs of the less-literate masses. It has forty-three pages and was written in late 1912 or early 1913. Mr. Bai's book is 6 in $(15.2 \mathrm{~cm}) \times 7^{1 / 4}(18.4 \mathrm{~cm})$ and was purchased in Beijing in May 2012.

Mr. Qian's Notebook [Qian xiansheng zhi chaoben 錢先生之抄本]. This handwritten notebook had no title. Mr. Qian's working notebook is filled with sample texts for matching couplets, divided into categories that reveal the prosperous and economically active community in which he lived. We think this community was Kaiping 開平 County, Guangdong 廣東 Province. The calligraphy was neatly done, the book is clearly organized, the pages are clean and of better than average quality. The cover and earliest pages are missing, but the pages intact are well prepared and the only calligraphy is that of Mr. Qian. The sixty-two pages of this book measure 63/4 inches $(17.1 \mathrm{~cm}) \mathrm{h} \times$ 4-7/8 inches $(12.4 \mathrm{~cm})$ w. I bought it in Hangzhou in June 2012.

A New Collection of Regular and Commercial Couplets 共和普通商用對聯新編 [Gonghe putong shangyong duilian xinbian], ed. Master of the Qingyunxuan [qingyunxuan zhuren 清雲軒主人] (n.p., 1915). This is a printed book of sample celebratory matching couplets that might have been used in Tonghua 通化, a city in southern Jilin Province, as indicated by the fact that the cover has that name on it. This is an example of printed editions of sample couplet texts available to anyone in 1915, around the time Mr. Bai in Chapter 7 was producing and selling celebratory scrolls. Collections such as this were useful for people who wished to write the scrolls for themselves or to earn income by writing these texts for paying customers. It is two volumes bound together, vol. 1 of nineteen folio pages, and vol. 2 of twenty-three folio pages. I bought this chaoben in Changchun in December 2012.

On the Foundation of Marriage (This Edition) Free of Mistakes [Hunyuanjiang wushi 婚元講勿失]. The text claims to lay out all the elements that must be in place to secure a successful marriage. Because spirits and forces abound, every precaution must be taken 
to carry out each small detail correctly in the planning and execution of the wedding. This text would have been used by a fortuneteller, a yinyang master, or a ritual specialist to calculate the most propitious time and manner to conduct the ceremonies. These specialists might have been the same person, because their skills and knowledge were not always sharply distinguished or specified. The text would have been a complete reference work for the task, because it even includes talisman [ $f u$ 符] on pp. 52-54. This work of sixty-eight pages is 7 inches $(17.8 \mathrm{~cm}) \mathrm{h} \times 4^{1 / 2}$ inches $(11.43 \mathrm{~cm}) \mathrm{w}$. I bought it in Beijing in September 2005.

One Thousand Three Hundred Words [Ch'on sambaekcha 천삼백자/千三百字]. At first glance, this fifty-eight-page manuscript from Korea, neatly copied onto handmade rice paper, appears to be a typical Chinese vocabulary list. My conclusion is that the book was written in 1966. The term "ceasefire" [chŏngjin sŏnŏn 정전선언/停戰宣言] was in common use in South Korea after the Korean War. Assuming this was used in the 196os, perhaps by a village school teacher to instruct his students in learning Chinese characters, which were in great use at that time, this document shows the extension of the Korean chaoben tradition well into modern times. The book is 8 inches $(20.32 \mathrm{~cm})$ $\mathrm{h} \times 7$ inches $(17.78 \mathrm{~cm}) \mathrm{w}$ and was bought in Seoul in January 2011.

Petitions to the Thunder Altar [Fengzhi chiling leitan 奉旨敕令雷壇]. The title page and earlier pages have fallen away from this sixty-seven-page book, so I assigned the title based on the first talismanic character to appear on the first extant page. The text is written on printed red-lined writing or accounting paper with columns marked in red lines. On the fold (the outer edge of the pages) of the paper is written "Increase wealth, gather treasures" [Zengjin jiyu 增金積玉], printed by the Hall of Stability [Tailintang 泰臨堂]. This type of printed paper format was popular from the late 18 oos through the Republican era. Drawings of some of the malevolent [sha 繁] forces are on pp. 25. Various spirit generals [shenjiang 神將] are described, along with incantations [zhou 咒] for approaching them to request their help. Based on dates appearing in the text, this was likely written between 1886 and 1900 . Bought in Beijing in January 2015, this is 9 inches $(22.8 \mathrm{~cm}) \mathrm{h} \times 10$ inches $(25.4 \mathrm{~cm}) \mathrm{w}$.

Popular Knowledge, Volume 3 [Tonggam, gwanji sam 통감 권지삼/通鑑卷之三], a history of the Chinese Eastern Han Dynasty (194-128 BCE), dated 189o. It is 12 inches $(30.48 \mathrm{~cm}) \times 81 / 4$ inches $(20.95 \mathrm{~cm}) \mathrm{w}$, and was purchased in Seoul in January 2011 . This appears at first glance to be a woodblock print done in a complete woodblock edition style. But a closer examination shows it to be entirely hand-copied. It was perhaps a student's workbook. In which the text is very clear and all the characters are carefully written. 
Prayers to the Dragon King [Longwang fashi 龍王法事]. The inside cover page has a more descriptive subtitle: "Recommended Memorials, Petitions and Certificates for a Religious Service” [Gongjin biao shu die fashi 貢進表疏牒法事]. It describes the sorts of memorials [zou 奏] and official requests [die 牒] that can be prepared to call upon the dragon kings for help. The dragon kings are addressed in this text by their Buddhist (Sanskrit) appellations. These deities are approached for help to bring rain and could also be requested to control floods. The text was written in the renyin 王寅 year, and 1902 seems a reasonable date, judging from the handmade paper and the twine binding of the work. Based on the cover title on red paper and subtitle inside on red-purple paper, plus abundant red circles in the text for punctuation, this was clearly used by a ritual specialist. It has thirty-four pages and measures 9 inches $(22.86 \mathrm{~cm}) \mathrm{h} \times 5^{1 / 4}$ inches $(13.33 \mathrm{~cm})$. I bought it in Beijing in 2010 .

Precious Mirror of the Li Family [Lishi chuanjia baojian 李氏傳家寶鑑]. This was written in 1907 by Li Yaguang 李亞廣. A handwritten record of 144 pages, it contains fairly detailed entries for all the generations, including additional paragraphs on the family property and business interests of family members. It could have been the written text in preparation for a printed edition. It has good comments about this family, which was proud of its commercial activities and real estate. The chaoben is $61 / 4$ inches $(15.9 \mathrm{~cm}) \mathrm{h} \times 5^{-1} / 8$ inches $(13 \mathrm{~cm}) \mathrm{w}$ and was purchased in Beijing in January 2008 .

Precious Repentances to the Three Primes [Sanyuan baochan 三元寶懺]. This handwritten account of seventy-five pages was rebound in heavier paper sometime in the 1950s or 196os, and it appears the title and the name of the altar where it was held were cut from the original cover and pasted onto the heavier new cover. In the same red paper as the title, the altar is given as Record of the Altar of the Mysterious Thunder Deity [Xuanmiao leitan zhi 玄妙雷壇誌]. The book is organized into three volumes, and each volume calls upon one of the Three Officials [Sanguan 三官] for assistance. On the first page of text, the title is given as "Precious Repentances to the Yoga Three Primes, Complete" [Yujia sanyuan baochan quanbu 瑜伽三元寶懺全部]. Yoga refers to the practice of meditation followed by Buddhists, Hindus, and Daoists. This text was copied in the autumn of 1863 , "Respectfully given by Mr. Tian Yicheng for use on the altar” [Jing yu Tian Yicheng xiansheng tanzhong yingyong 敬於田一澄先生壇中應用; p. 75$]$. The book is $9^{3 / 4}$ inches $(24.76 \mathrm{~cm}) \mathrm{h} \times 5^{1 / 2}$ inches $(13.97 \mathrm{~cm}) \mathrm{w}$.

Records Prepared in 1811 [Bunka hachinen fuyu okakitsuki 文化八年冬御書附]. The subtitle on the front cover of this chaoben from Japan is "Records Handed to the Official at the Time of His Transfer" [Odaikan kōtai no toki no hōsesōrōbun 御代官交代之時之 報請候分]. This handwritten collection of documents was prepared for the officer in 
charge of the shogun's lands [bugyo 奉行] at the time the officer was transferred from the rural estate to the capital at Edo. This collection was then given to the new officer in charge, who proceeded to the estate. On pp. 48 and 49, we see that these documents were copied out by Watanabe Seihei 渡邊瀨兵衛, who was the shogunal administrator of Osaka (then called Ōsaka machi 大坂町). His seal in black is on this collection. On the back cover is the phrase "A total of thirty sheets have been put together here" [uwagami tomo sanjūmai 上紙共三拾枚; p. 54]. This collection is pure bark paper made from white mulberry. It shows many insect holes. The paper deteriorates very slowly, leading to the popular conclusion that bamboo paper will last for five hundred years, but mulberry bark paper will last for one thousand years. The book is $93 / 4$ inches $(24.76 \mathrm{~cm})$ $\mathrm{h} \times 63 / 4$ inches $(17.15 \mathrm{~cm})$. I bought it in Tokyo in August 2007 .

The Red Shore [Hongpu 洪浦] is a manual used by a professional litigator [songshi 訟師]. He might have set up a table at a periodic market or at a temple fair where he was approached by people needing his services. Common people sometimes had a grievance they wanted to take to the officials at their local government office [yamen 衙門], hoping for an official sanction of their complaint and some redress to their problem. Sometimes relatives fought among themselves, and the only way to settle the issue would be to consult with a litigator outside the family. In more serious cases of theft, or rape, or repudiation of a recognized agreement, papers could be prepared by the litigator and presented to the local officials. Six brief legal cases are outlined in this handwritten chaoben on pp. 1-16. The remainder of this booklet until p. 44 goes into detail about a system of fortunetelling by casting dominoes. It appears the man who worked as a litigator was also a fortuneteller, and this was a reference book he probably wrote and used. The paper is bamboo, with some straw and some bark mixed in. The paper is thin, and not of bad quality. The booklet is $6 \frac{1 / 4}{4}$ inches $(15.87 \mathrm{~cm}) \mathrm{h} \times 4^{1 / 2}$ inches $(11.43 \mathrm{~cm})$ w. It was purchased in Guilin in September 2005 .

Repentance in Homage to Heaven, Complete [Chaotian chan, quan quan 朝天懺, 全券]. This is a handwritten text addressed to the Jade Emperor. It was copied in the Hall of Heaven's Emolument [Tianlutang 天祿堂]. The full title of the text, written on the first and final inside pages is "Correct Way, Thirty-Eight Apologies of Repentance in Homage to Heaven” [Zhengyi chaotian sanba xiezui fachan 正一朝天三八謝罪法懺]. The phrase "correct way" or "orthodox unity" [zhengyi 正一] probably refers to the Zhengyi sect of Daoism, which today is more popular in South China than in North China. This is possibly a Republican-era text written on machine-made paper. It has sixty-three pages and measures $10^{1 / 2}$ inches $(26.67 \mathrm{~cm}) \mathrm{h} \times 5^{-2} / 3$ inches $(14.6 \mathrm{~cm}) \mathrm{w}$. It was purchased in Beijing in March 2009, but is originally from Hengyang 衡陽, Hunan 湖南. 
Repentances to the Supreme Three Primes to Forgive Sins [Taishang sanyuan youzui fachan 太上三元宥罪法懺; written on the inside pages as Taishang sanyuan miezui miaochan 太上三元滅罪妙懺]. The collection is in three volumes, totaling forty-seven pages. Each volume addresses one of the Three Officials [Sanguan 三官] and gives the text of memorials [ $z o u$ 奏] that can be written to approach them, often with the words following the text "after delivering this memorial, it is burned" [toubiao fenhua 投表 焚化; p. 30]. This includes the phrase "To Revere Heaven on the $15^{\text {th }}$ day of the first month ...” [Tianzungyan zhengyue shiwuri ... 天尊言正月十五日 ...; p. 3]. This shows the conflation in which the beginning of the first yuan [yuanxiao 元宵] on January 15 is also addressed to the First Yuanguan [Shang yuanguan 上元官], as discussed in Chapter 1. This text was copied in the Hall of Auspiciousness [Ruitang 瑞堂], and it was copied by Qin Yicheng 秦一誠, who was searching for the Dao but had not yet achieved it, as he wrote of himself at the end of vol. 2, p. 30 , "have not achieved the Dao” [mo Dao 末道]. The text is $9 \frac{3}{4}$ inches $(24.76 \mathrm{~cm}) \mathrm{h} \times 81 / 4$ inches $(20.95 \mathrm{~cm}) \mathrm{w}$ and was purchased in Beijing in March 20o9, though it originally came from Hengyang 衡 陽 in Hunan.

Repentances to the Three Officials [Sanguan chan 三官懺]. This text was hand-copied in September 1876 . The title as given on the inside pages is "Ceremony of Repentances to the Three Primes" [Chaoli Sanyuan chanfa 朝禮三元懺法]. The participant is frequently advised to "Carry out the ceremony with a determined heart" [Zhixin chaoli 志心朝禮], and, for emphasis, someone put three red circles above this phrase in vol. 1, p. 24 and elsewhere in the set where the phrase appears. The copyist identified himself by his given name as Mr. Yuruo [Yuruo shi 雨若氏] of the Clear World Pavilion [Shiqingtang 世清堂]. Vol. 1 [zheng 正] has thirty-five pages; vol. 2 [zhong 中] has twenty-two pages; and vol. 3 [xia 下] has twenty pages. Its volumes are $81 / 4$ inches $(20.96 \mathrm{~cm}) \mathrm{h} \times$ $5^{1 / 4}$ inches $(13.33 \mathrm{~cm}) \mathrm{w}$. This is another of the books originally gathered in Hengyang, Hunan. I bought the three string-bound volumes in Beijing in 2010.

Rhyming Dictionary [Yinyun ziyi 音韻字義]. The copyist's name was Dong Chengxiang 董成祥. The undated book lists together characters that have the same sound, with an explanation for each sound or a compound where it is used. The dictionary could be used to write poetry, or it could be for the purpose of increasing vocabulary. The handmade paper is of medium quality. All the characters are written in the complex form. This appears to be a Republican-era text. The forty-eight-page book is $81 / 4$ inches $(20.96 \mathrm{~cm}) \mathrm{h} \times 4^{1 / 2}$ inches $(11.43 \mathrm{~cm}) \mathrm{w}$, bound in twine. I bought it in Beijing in May 2010.

Riches Bestowed [Qianjinfu 千金賦]. This was likely intended as a reference book to be read, perhaps as a text used by a yinyang master [yinyangshi 陰陽師]. Sections 
of the booklet cover marriage and childbirth, and most sections make reference to supernatural forces, such as stars and deities that influence human affairs. Based on its use of the phrases "big foreign money" [dayangpiao 大洋票] and "national currency" [guobi 國幣], both terms used in the Republican era (p. 69), this is probably a Republican-era text. A list of the streets in the town in which the writer was working is on p. 73, so old city maps would help to pinpoint the city. Some of those street names were: Min jie 民街, Huigong jie 恵工街, Sunjiawan jie 孫家灣街, Chongde jie 崇德街 (p. 73). My research indicates that the city was Chaoyang 朝陽, Fengtian 奉天 Province. This is a work of seventy-four pages written in a very good calligraphic hand on poorquality handmade paper. The ink still looks crisp. It has a section along the outer folded edge where a goat or a rat took a bite out of the book and the animal's saliva stained the surrounding paper. The paper is of bamboo with some long bark fibers. It is $81 / 2$ inches $(21.59 \mathrm{~cm}) \mathrm{h} \times 5^{1 / 4}$ inches $(13.34 \mathrm{~cm}) \mathrm{w}$, a size convenient to be a reference book. It was purchased in Beijing in August 2005 .

Ruili Accounts [Ruili qingchaozhang 茌裡清抄賬]. This company operated like a bank or a moneylender in Shandong 山東 Province. Next to many of the business or individual names listed in the volume are the names of the local community, often a village or small hamlet. By placing all these locations geographically, we can see the area in which the Ruili Company operated; thirty-six place names are given. Each account is listed with the name of the responsible individual, and sometimes the account is listed by the name of the company. The Ruili Company recorded commitments and accounts in this volume between 1924 to 1932. Like most commercial ledgers, this uses runninghand script [xingcaoshu 行草書], making it hard to decipher many of the characters and numbers. The paper used was machine-manufactured accountant's forms with columns in red ink and marked "Increase Disciplined Flourishing" [Zengshunxing 增 順興]. The book is $7^{1 / 4}$ in $(18.41 \mathrm{~cm}) \mathrm{h} \times 6$ in $(15.24) \mathrm{w}$. It has 298 pages and was purchased in Beijing in 2011.

Secret Text for Summoning the Snake [Shechuan miben 蛇傳秘本]. The bulk of the twenty-nine-page handwritten work is incantations calling on Laozi for assistance. It is based on the idea the venerable Laozi assumed the shape of a snake, which has often been seen as one form that a dragon could take. On pp. 3-4 and 9-18 are ten incantations [zhouyu 咒語] all addressed to Laozi 老子 by his official title Most Ancient Noble [Taishang laojun 太上老君]. They are all titled “respectfully submitted” [ fuyi 伏 以] and end with the words "I petition" [wu feng 吾奉] as well as the standard phrase used to conclude Daoist incantations and ritual petitions to the deities, "Promptly, promptly, decree in accordance with the statues and ordinances" [Jiji ru lvling 急急如 律令]. The paper is of poor quality. Many pages are on paper with a grid printed in red, which is common in account books and diaries in the late Qing or the early Republic. 
The phrase in the fishtail of the outer folded edge of each page is "From One Dollar, [One Can] Earn Great Profit" [Yida wanli一大萬利]. It is 63/4 inches $(17.14 \mathrm{~cm}) \mathrm{h} \times 7^{1 / 4}$ inches $(18.41 \mathrm{~cm})$ w. I bought it in Beijing in June 2014.

Selected Essays [Jingxuan shiwen 精選時文]. I assume this chaoben was kept by an instructor at the Home Study Academy [Jiaxiu tang 家修堂], and the date on the cover is the bingzi 丙子 year. Judging from the topics of the essays, I think 1876 is a reasonable date for this collection because essays from the 1920 and 1930 had nationalistic rhetoric, but these essays seem to look more to classical tales for inspiration. The instructor's comments critiquing the essays were pithy and useful for the students. For example, “The style is good. Don't include too many points" [Se dangxing; bude duojian 色當行 ; 不得多見; p. 22]; “Keep your eye on the peak. Pull together your energy. You will do well in the exam!" [Yangao yuding; lida yushen. Tongshizhong jiezuo ye 眼高於 頂 ; 力大於身。童式中傑作也; p. 28]. The book is 7 in $(17.7 \mathrm{~cm}) \mathrm{h} \times 5$ in $(12.7 \mathrm{~cm}) \mathrm{w}$. It has 244 pages and was bought in Beijing in May 2012.

Six-Word Vocabulary List [Liuyan zazi 六言雜字]. This is a work of twenty-three pages, bound with string, and written on handmade paper that contains a lot of chaff but took the ink well. The copy was made by Wang Juhe, who wrote "earnestly recited by Wang Juhe" [Wang Juhe qinsong 王聚和勤誦], which could mean he copied and studied the text or that he actually wrote it. This is probably a Republican-era copy. The author uses many nonstandard [suzi 俗字], popular forms of the characters in this text. A particularly interesting section is the concluding pages (pp. 21 and 22), where writer Wang Juhe had an out-of-body experience by dreaming he had died but could see everything going on around him. The paper is made from bamboo with some bark mixed in and makes a sharp sound when lightly crinkled. A lithograph vocabulary list with this title was published in the Republican period (1912-1949) by Putong shuju in Shanghai. I compared some phrases from that work to the copy discussed here, and they do not seem to be the same. This vocabulary list was purchased in Beijing in 2015 and measures $7^{3 / 4}$ inches $(19.68 \mathrm{~cm}) \mathrm{h} \times 4^{3 / 4}$ inches $(12.06 \mathrm{~cm}) \mathrm{w}$.

Shortcut to Vocabulary Words [Jiejing zazi 捷徑雜字]. This is a woodblock printed volume of fifty-four pages. A handwritten cover gives it a date of January 1, 1950, but the pages and the paper of the text indicate a date more than thirty years earlier. The cover was written by Yan Shuwen [Yan Shuwen dushu 顏書文讀書; p. 53] and was also used by his relative Yan Xibang 顏錫榜, whose name is on the front cover as well. They have also written some words on the cover that might have appeared on the original: "Popular Pocket Edition" [Jiayong xiuzhen 家用袖珍]. “Guizhou for felt rugs and silk” [Guizhou jijuan 貴州罰絹] and “magua jacket to protect from the wind" [magua pifeng 馬社披風] are listed on p. 46. These give clues about the origins of 
this text. The reference to Guizhou might indicate it was written in Southwest China, although products from Guizhou likely had a national reputation. The magua was a Manchu-style short coat that became very popular in China and was worn throughout this period. In contemporary China, it is often called a "Tang-style coat" [Tang zhuang 唐裝], which is not historically correct but shows how the Chinese people have made this Manchu import their own. A vocabulary list with this title was published as a lithograph copy in 1871 issued by Yue Chongde 岳崇德 and edited by Yue Heng 岳衡. The title is very generic, however, and, since I have not seen the lithograph copy to compare the contents, I cannot tell whether they are similar. This book is $81 / 4$ inches $(20.95 \mathrm{~cm}) \mathrm{h} \times 5$ inches $(12.7 \mathrm{~cm}) \mathrm{w}$. I bought it in Beijing in July 2011.

Song by the Wenchang Emperor Advocating Filial Piety [Wenchang dijun qinxiao ge 文昌帝君勤孝歌]. It was copied in the Hall of Respecting Goodness [Zongshan tang jinglu 宗善堂敬錄]. This thin book has fourteen pages written in a quite good hand, indicating a person who was comfortable and accomplished at using the writing brush. It is bound in twine, and the paper seems of mediocre quality, rather rough and coarse. Wenchang is one of the deities in popular Daoism in China who is associated with those in professions that use the writing brush, such as accountant, government bureaucrat, teacher, and student. In this text, the popular Daoist deity is called upon to teach sons and daughters how to follow the important Confucian value of filial piety [xiao 孝], or respect for one's parents and family members. The back cover mentions a date: "Respectfully recorded in the late summer of 1886" [Kan zai bingxu nian mengxiaxia huangonglu 看在丙戌年孟夏下浣恭録; p. 14]. The term xiahuan [下浣] means during the last ten days of the month. The bingxu 丙戌 year fell in 1826, 1886, and 1946. I think this manuscript was copied in 1886 . The manuscript was physically copied, as recorded on the back cover, in the Studio of Orderly Study [Luyu siqixue shi 錄於思齊 學室], probably the copyist's studio. On pp. 10-13, some characters that are apparently miswritten indicate clearly that this text was copied from another manuscript, possibly by a student whose teacher then made the corrections in red. The book is 9 inches $(22.86 \mathrm{~cm}) \mathrm{h} \times 4^{1 / 2}$ inches $(11.43 \mathrm{~cm}) \mathrm{w}$ and was bought in Beijing in September 2005 .

Standard Elementary Education [Zhengyi qimeng 正義啓蒙] is a lithographed text, but the pages appear in the format of woodblock pages, with a border around the text and the title in a column on the outer fold of each page. The book actually discusses classical phrases taken from the Lunyu 論語 [Analects of Confucius] and how to write bagu 八股, the eight-legged essays that were once used as part of the official government examinations. The section on eight-legged essays is in vol. 2, side $1 \mathrm{~B}$ to $2 \mathrm{~B}$, and is dated June 1898 . Most sections are brief and useful as an introduction for students at the beginning of their studies. It is two volumes bound as one (vol. 1, sixteen folio leaves, vol. 2, fifteen folio leaves). On vol. 1, side A, is the preface from an earlier 
edition of the book titled "Preface to Beginning History Studies" [Shilun chujie $x u$ 史 論初皆序]. This preface is dated June 1898. A date of 1901 appears in the text on vol. 1, side $\mathrm{B}$, but the volumes, the only two available to me at the time, were published in Shanghai by Guangyi shuju in 1916. A possible one-time owner of this book was Liu Zhilong 劉志龍, who wrote his name on the first page, in fountain pen. I bought this in Guilin in September 2005.

Student Li Hongduo [Xuesheng Li Gongduo 學生李洪鐸]. He was born in 1937. This is his diary/workbook from 1951, when he was a middle school student in Ruichang 瑞昌, Jiangsu 江蘇 Province. The thirty-four-page chaoben tells both about his lessons and the pro-Russian atmosphere at the school. He wrote down his weekly schedule, and his name is proudly stamped on p. 13. He also tells us the names of his best friends. It is bound in twine on poor-quality browned paper. It is $7^{3 / 4}$ inches $(19.68 \mathrm{~cm}) \mathrm{h} \times 5^{1 / 4}$ inches $(13.34 \mathrm{~cm})$ w. It was bought in Beijing in July 2011.

Supreme Morning Text for Becoming an Immortal [Taishang xiuzhen chenke 太上修 真晨課]. This is a handwritten copy of a Daoist text meant to be recited in the morning as part of the devotions that begin the day, and at places in the text are indications that a particular phrase should be spoken three times: "Ever pure, ever serene, most supreme heavenly worthy, three times" [Changqing changjing wushang datianzun, san sheng 常清常靜無上大天尊, 三聲; p. 2], along with prayers to “cleanse my heart” [jingxin shenzhou 凈心神咒; p. 3], “cleanse my mouth” [jingkou shenzhou 凈口神咒; p. 3]; “cleanse my body" [jingjing shen shenzhou 凈淨身神咒; p. 4]. It proceeds to address the land god [tudishen 土地神; pp.4-6] and the Three Officials [Sanguan 三官; pp. 11-48]. These prayers must have produced a fresh and clean and confident feeling in the person reciting them. The text was written in a good hand, probably by a Daoist monk or a ritual specialist (in a style called the sutra script or block standard [xingkai 形楷] often used by religious-affiliated persons in the Qing and Republican periods). The forty-eight-page handwritten text is not dated and could be a late Qing (1890-1911) document as easily as a mid-Republican-era (1920s-1930s) chaoben. I bought this in Shanghai, but someone (in the 1940s or later) wrote in ink the place name Kui 奎Village, Wujin 武進 County. Today this area is called Wuzhou 武洲 District, Changzhou 常州, Jiangsu 江蘇 Province. The book is bound in twine. The book is $8 \% 4$ inches $(22.22 \mathrm{~cm}) \mathrm{h}$ $\times 5$ inches $(12.7 \mathrm{~cm})$ w. I bought it in January 2012 .

The section on "cleanse my heart," "cleanse my mouth," and so on, is a standard introduction to beginning the chanting of a sutra text. A similar set of practices appears in Morning Altar Text [Zaotan gongke 早壇功課], an eighty-three-page hand-copied text. The original front and back covers have fallen off, which means the loss of the last page, which normally has the date and the name of the "hall" or "studio" name where the text was copied. The introductory cleansing portions of the text are on pp. 2-4. This 
text highlights the names of several Daoist deities. The second half of the book, pp. 5383, is an Evening Altar Text [Wantan gongke 晚壇功課] that begins by addressing the Celestial Lord Who Relieves Suffering [Taiyi jiuku tianzun 太乙救苦天尊; discussed in Chapter 8], and it goes on to address other deities. Judging from the paper quality, very clean appearing almost machine-made, this text might be from the 193 os. It is $81 / 2$ inches $(21.59 \mathrm{~cm}) \mathrm{h} \times 5^{3 / 4}$ inches $(14.61 \mathrm{~cm})$ w. It was bought in Beijing in January 2015 .

The standard cleansing text continues to be used today, as can be seen from the text in "The Efficacious True Sutra of the God of Medicine" [Lingying Yaowang zhenjing 靈應藥王真經] on pp. 4-6. This forty-six-page offset printed pamphlet was compiled and printed jointly by the Hubei Province Taishanguan Monastery of Shiyan City [Hubeisheng shiyanshi, saiwudang daoxie, taishanguan 湖北省, 十堰市, 賽武當 道協, 泰山觀] and the Beijing Imperial Fire God Temple [Beijing chijian Huode zhenjunmiao 北京敕建火德真君廟], in 2014. The book is labeled a precious book admonishing people to do good deeds [shanshu 善書] that is not to be sold but distributed gratis. This pamphlet is 8 inches $(20.32 \mathrm{~cm}) \mathrm{h} \times 5^{1 / 2}$ inches $(13.97 \mathrm{~cm}) \mathrm{w}$.

\section{Sutra of the City God, Sutra of the Dead [Chenghuang jing Duwang jing 城隍經度亡} 經]. The Sutra of the Dead of the title is inside this text, labeled as the Sutra of the Six Hells [Liu yu jing 六獄經], on pp. 17-43. This is actually composed of several shorter Buddhist-inspired texts. For example, the Precious Sutra of the Correct Teaching of the Dizang King [Dizang wang 地藏王] about the Blood Mountain as Revealed by the Buddha [Foshuo dazang zhengjiao xueshan miaojing 佛說大藏正教血山妙經] begins on p.18. An unfortunate woman's soul [ hun 魂] was consigned to this purgatory because she had died in childbirth and had lost a lot of blood. As described in the Sutra of the Six Hells she might have to experience a mountain of blood [xue shan 血山; pp. 1825], a lake of blood [xue hu 血湖; pp. 26-29], a sea of blood [xue hai 血海; pp. 30-33], a pool of blood [xue chi 血池; pp. 33-37], or a vessel of blood [xue pen 血盆; pp. 37-43]. Although the adjectives used to refer to these places tell of filth and dirt [huiwu穢污] and filthy blood [huixue 穢血; p. 34], and although the various tortures and the ghosts who rule this realm, the judges and small ghosts [panguan xiaogui 判官小鬼; p. 35] are in the unwelcome place, still there is redemption, as shown by the phrase "Look into the vessel and pond of blood and there are five lotus blossoms coming forth" [Kanjian xuepen chizhongyouwuduo lianhua chuxian 看見血盆池中有五朵蓮花出現; p. 41]. The lotus is a pure white flower that grows in the mud, a Buddhist symbol of forgiveness and of overcoming the filth of the world to reach a higher sphere. The Dizang King was a deity able to descend to the netherworld in order to free the souls there and speed their rebirth. A date that appears is the wuzi 戊子 year, which is either 1888 or 1948 . Based on the text and the paper, a date of 1888 seems reasonable. At some point, the booklet was falling apart, so it was pasted onto a notebook of machine-made paper, making a date of 1948 also possible. The text may have been written by Xia Linchang 夏林昌, whose 
name appears. Xia was in Quanzhou 全州, Guangxi 廣西 Province, about 100 miles northeast of the often-visited tourist spot of Guilin 桂林. Quanzhou was a key market city and trading center and was seen as the transportation entrance to Guanxi, linking it with Hunan 湖南 Province. This text may have been written on the unused side of Mr. Xia's ledger. It is folded like a typical Buddhist sutra in the "accordion-fold" style, in this case with forty-three "pages." It is 9 inches $(22.86 \mathrm{~cm}) \mathrm{h} \times 4^{1 / 4}$ inches $(10.79 \mathrm{~cm})$ w. I bought it in Beijing in May 2012.

Talking about Vocabulary Lists [Shuo zazi 說雜字]. These are the first words of the text, which I selected as the title in the absence of a cover. Its official title as printed on the fishtail [yuwei 魚尾, typically used in woodblocks straddling the outer fold to print the title or perhaps a motto of some sort] of the folded pages is Sanyan zazi 三 言雜字 [Three-Character Vocabulary List]. The focus of this vocabulary list is opening a business, calling friends together to help, dealing in a correct way with officials, and conducting oneself as an upright business owner. Most of the middle pages in the text list the types of shops and stores that one could open. This is an extensive list that allows us to reconstruct a late Qing or Republican-period commercial street in China. The examples given are for various types of retail stores. Judging by the contents, the paper used, and the lithograph process, this printed book was produced between 1912 and 1927. This is a lithographed print of ten folio leaves that I bought in Hangzhou in 2012. The book is $63 / 4$ inches $(17.14 \mathrm{~cm}) \mathrm{h} \times 4^{3 / 4}$ inches $\left(9.5^{2} \mathrm{~cm}\right) \mathrm{w}$.

Tang Family Genealogy [Tangshi jiapu 唐氏家譜]. This is a handwritten genealogy of only thirteen pages. The cover has no writing on it and no title. The entries for each generation are brief and generic. My research indicates that this family could trace its roots to the Ming dynasty and in 1944 (when I think this was written) was in its twentyfirst generation. I believe both the father and his son surnamed Tang 唐 wrote the final pages of this work together. Their view of the family was the standard inherited idea of a patriarchal family, in which the men might sometimes give themselves honorific names [ hao 號] and enjoy concubines. At the same time, the son in his entries followed his heart, rather than strict reporting rules. He wrote about his female cousins who may have died or married into another family. Female family members were often omitted from their own family's genealogy and entered, instead, in their husband's family record after their marriage. This work is $9^{1 / 2}$ inches $(24.1 \mathrm{~cm}) \mathrm{h} \times 5^{1 / 2}$ inches $(14 \mathrm{~cm}) \mathrm{w}$, and I bought in Ji'nan, Shandong, in March 2009.

Three Items for Mr. Xu [Xushi sanzhong 徐氏三種]. This is a good example of handwritten materials copied and bound by a professional scribe, who then put his shop's seal on the work. The materials were to be used by Teacher Xu for his classroom, except perhaps for the recipe for an herbal sleeping aid, which would have been more suit- 
able for someone middle-aged. Because this has five binding strings, I believe it was bound by a Korean, and we know that at the time many Koreans lived in Panshi 磐石, Jilin 吉林 Province, where the copy shop was located. It contains a recipe for an herbal sleeping medicine, a complete text of the Qianziwen 千字文 [Thousand-Character Classic], a riddle [dasizi 打四字], and some list of names most likely of his students, their addresses, and comments on their names. This is $93 / 4$ inches $(24.76 \mathrm{~cm}) \mathrm{h} \times 83 / 4$ inches $(22.22 \mathrm{~cm}) \mathrm{w}$, which gives it a square shape, similar to Korean string-bound books. The book has 103 pages including the front and back cover. I bought it in Beijing in September 2005 .

A woodblock publication with the same title appeared in the early Qing. It consists of three volumes, each containing a text popularly used in elementary education: the Sanzijing 三字經 [Three-Character Classic], the Thousand-Character Classic, and the Baijiaxing 百家姓 [Hundred Surnames]. The set was based on a collection from an earlier Song 宋 dynasty (96o-1279) edition compiled by Wang Yingling 王應麟. The Qing collection was annotated by Wang Xiang 王相 and edited by Xu Shiye 徐士業. It was reissued in 1821 by the Fuchuntang 富春堂 in 1821. Therefore, when Teacher Xu made a copy (I assume in about 1883) to use in his classroom as a textbook, he was likely familiar with the title because the reissued edition was still in circulation, so kept that title for his copied materials. Indeed, he had the Thousand-Character Classic reproduced, but the other copied items were for his own use in the classroom. Was that because he did not have much money and could not pay to have the other two titles copied?

Using the Western Calendar as a Guide to Writing (Your Fortune) through the Five Stars [Xiyang dili liangtianchifeixie wuxing 西洋地曆量天尺飛寫五星]. The astrologer who prepared this horoscope wrote in a distinctive calligraphic script, using the calligraphy style known as the "sutra script" or "block standard" [xingkai 形楷], in which certain strokes are bold. He also affixed many seals in red to make this work visually attractive. He also praised his own abilities, calling himself "an award-winning master” [bizizhongshang 筆資重賞; p. 3]. This predicts the fortunes of a man named Zeng Bingyan 曾炳炎. It appears that Mr. Zeng was born in 1871. In 1921, when he was fifty years old, he asked the fortuneteller to predict the next ten years of his life. This analysis is indicated by his birth date on p. 4 and a sentence on p. 20: "Now you are fifty-one years old" [Mujin wushiyi sui 目今五十壹歲]. Thus this booklet was probably written in 1921 and contains predictions for 1922 to 1931 . It is a work of thirty pages, $8 \% 4$ inches $(22.22 \mathrm{~cm}) \mathrm{h} \times 5^{1 / 4}$ inches $(13.33 \mathrm{~cm})$ w. I purchased it in Beijing in September 2005 .

Various Words Offered to the People [Kuanzhong zazi 欵眾雜字]. This vocabulary list begins by talking about the forces of the universe, the stars, and the deities. It goes on to present lists of words for plants, animals, and government and then talks about 
the family and adds comments about conventional morality, which tells young men to avoid fighting in the streets and forcing themselves on women. Three poems by one of the Guo family who prepared this booklet conclude it on the last page (p. 30). The book was copied by Guo Changyun 郭長雲, who added the word “copied” [ $j i$ 記] after his name. At a later point, his relative Guo Shengkui 郭生魁 wrote (different brush and ink) his name and indicated his ownership of this particular volume, by adding the words "recorded" [ jishu 記書] next to that of the original copyist on the front cover. This is a handy pocket-size booklet, purchased in Beijing in August 2007, which measures $5^{-1 / 5}$ inches $(13.97 \mathrm{~cm}) \mathrm{h} \times 4^{3 / 4}$ inches $(12.06 \mathrm{~cm}) \mathrm{w}$.

Vocabulary for Young Students [Youxue zazi 幼學雜字] with the handwritten cover written by Yan Hailin 閻海林. This is a printed work, with the full title printed on the first page as "A New Vocabulary List Illustrated for Young Students" [Huitu Zhonghua youxue xinzazi 繪圖中華幼學新雜字]. This book of eighteen folio leaves appears to have been printed during the early years of the Republic, probably while Yuan Shikai was president (1912-1915). Each vocabulary word is illustrated. On side A of the first leaf, the titles of the official offices in the new government are listed, each with a simple drawing that seems to represent the official. The flag is the five-colored flag of the new Republic. A drawing of "Jesus" on side A of the second leaf might be one of an Arab merchant. The booklet includes a great list of late Qing and early Republic items of daily use, all illustrated with a simple line drawing. It is $73 / 4$ inches $(18.64 \mathrm{~cm}) \mathrm{h} \times 5$ inches $(12.7 \mathrm{~cm}) \mathrm{w}$, and I purchased it in Beijing in May 2010.

Vocabulary List in Five-Character Verses [Wuyan zazi 五言雜字]. The text originated in earlier times, probably in the Qing period, but the edition I have was copied in 1982. It was written by Zhang Degong 張德恭, who used a brush to write traditional complex characters [fantizi 繁體字]. The thirty-eight pages were copied on modern machinemade paper, bound in string. A few other brush-written works by Mr. Zhang dated between 1983 and 1992 were available from the same bookseller. A reference to mutton and dog meat (p. 23) and to Manchuria makes me think the original text was written in North China. It is 8 inches $(20.32 \mathrm{~cm}) \mathrm{h} \times 6$ inches $(15.24 \mathrm{~cm})$ w. I bought this in Beijing in June 2013 .

Vocabulary List of the Local Dialect [Fangyan zazi 方言雜字]. The cover tells us the book was copied by Wang Tian [Wang Tian shudu 王田書讀] and read and recited by (probably his relative) Wang Zhen [Wang Zhen songdu 王禎誦讀]. It was probably copied in 1915, based on texts from an earlier period. The phrase "local dialect" in the title means "common" or "colloquial." The cover indicates it dates to the yimao 乙卯 year, which could have been $1855,1879,1915$, or 1939. The text, which refers to a cold northern climate, speaks of raising children, following the annual ceremonial cycle, 
and dealing with fellow human beings. This work is $81 \frac{1}{2}$ inches $(21.59 \mathrm{~cm}) \mathrm{h} \times 5$ inches $(12.7 \mathrm{~cm}) \mathrm{w}, 128$ pages bound in string. I bought it in Beijing in January 2010.

We Petition [Fuyi 伏以]. This work has no cover or title, so I assigned this title based on the first characters on the first page of text. The work includes talisman [ $f u$ 符] and incantations [ zhou 咒] to approach the deities and request their help. The thunder god [Leiting 雷霆 or Leigong 雷公] is addressed (pp. 31-33), followed by the snake [she 蛇] linked to the Nine Dragons [Jiulong 九龍] who bring rain (pp. 34 and 35). Drawings of various ghosts to be petitioned and controlled by Daoist priests are in this chaoben. Drawings of many deities and marshals or spirit generals [yuanshuai 元帥] who can assist humans in need are listed (pp. 37-48), along with talisman that are effective with them. A book of this large size would be good for instructional purposes. It is 11 inches $(27.94 \mathrm{~cm}) \mathrm{h} \times 7^{1 / 2}$ inches $(19.05 \mathrm{~cm}) \mathrm{w}$ and has sixty-six pages. I bought it in Beijing in January 2015 .

Writing Talisman [Shu fu fashi 書符法事]. This chaoben was “copied in the autumn of 1895 during the Qing dynasty" [Daqing guangxu yimo ershiyi nian meng qiuyuezhong huanchaoteng 大清光緒已末二十一年孟秋月中浣抄謄] by Huang Yongyuan 黃湧泉, whose religious name was Huang Daozong 黃道宗 [Huang of the Dao Faith]. He placed his seal prominently on the cover of the book and equally prominently throughout the text. When using either seal, his name was followed by $j i$ 記, meaning he was the copyist or writer. He also stamped one of his seals on the inner fold of every page. He may have done this to gain merit with the deities for having written the text and certainly to record the fact that he had produced the work. Finally, it appears Huang was in a trance when he wrote pp. 18-21, likely possessed by the spirits, and he began writing talisman in a larger and wild script. This was probably done in public, with other believers watching him. The ceremony was likely conducted for the benefit of a customer who desired guidance from the spirits. Huang must have been a ritual specialist of some renown who had his stamps and writing brush prepared to receive the spirit's responses and to record them. The idea that he called the deities down to earth, thus reversing the places of heaven and earth (because the heavenly deities were now down on earth) as part of his trance state, can be seen in the phrase "Rotate heaven and earth, heaven and earth are rotated; The many gods and evil spirits, are all displaced" [Lunzhuan tiandi. tiandi lunzhuan; zhuduo shensha haihuibi 輪轉天地, 天地輪轉; 諸多神鞄, 還迴避; p. 18]. It appears a donkey took a large bite out of one corner of this booklet. This work of twenty-one pages is 8 inches $(20.32 \mathrm{~cm}) \mathrm{h} \times 5^{1 / 2}$ inches $(13.97 \mathrm{~cm}) \mathrm{w}$ and was purchased in Beijing in September 2005.

Xue Family Genealogy: Carefully Copied with Additions by Sixteenth-Generation Xue Zhonghe [Xueshi jiapu: shiliu shisun Xue Zhonghe jinchao bingbu 薛氏家譜：十 
六世孫薛中和謹抄并補]. This copy, dated 1982, uses bleached machine-made paper of good quality. Mr. Xue, age sixty-eight when he wrote this copy, used traditional complex characters [fantizi 繁體字] throughout, although simplified characters had been officially taught and used in China since the 196os. The family claims its origins from Emperor $\mathrm{Wu}$ 武 (r. 141-88 BCE) of the Zhou dynasty, and its geographic origins were in Lin 臨 City in southern Shandong Province, as indicated in Mr. Xue's introduction. At some point, the family relocated to Jiading 嘉定, an important commercial transfer point and an area where many Confucian scholars were produced. Today Jiading is considered part of the northern suburbs of Shanghai. Jiading is famous as the city that resisted the Manchus strongly, provoking them into carrying out a three-day massacre [Jiading sanri tusha 嘉定三日屠殺] of its residents because of their loyalty to the previous Ming dynasty. Mr. Xue copied most of this history from an uncle, who was living in Shanghai just before the Cultural Revolution (1966-1976), and writes that the manuscript barely survived that political upheaval and the Red Guards, who came to search for such examples of "feudal" thinking. The work has handwritten maps to family graves in the Jiading area. This work of nineteen folio (folded) pages is 11 inches $(27.94 \mathrm{~cm}) \mathrm{h} \times 6^{1 / 2}$ inches $(16.51 \mathrm{~cm}) \mathrm{w}$ and was purchased in Shanghai in January 2013 .

The Xue Family Hideout, Part 6; Court Cases of Magistrate Shi [Xuejiawo, di liu juan; Shi gong'an 薛家窩, 第六卷; 施公安]. Shi Shilun 施世綸 (d. 1722) was a county magistrate in Fujian 福建 Province. Despite considering these fictional court cases, they have plots that are similar to those in adventure and martial arts stories. It is generally accepted that the original author of the stories was a poorly educated person on the fringe of the official class, which means he was considered to be a member of the pingmin. Huang Tianxia 黄天霞 (note the pun on his name, which sounds like "Huang Is Everywhere") is the hero, who solves all the mysteries. The Xue family is a group of water-borne river pirates who belong to the Jiangxi Gang [Jiangxi bianzi 江西扁子]. This chaoben is an example of a storyteller's text [pingshu 評書]. The text was meant to be read aloud, so it contains rhyming poetry mixed in with the dialogue in the story, which is written in a simplified classical style that was close to spoken Chinese. Some scholars classify these as written versions of oral stories [huaben 話本]. This volume used paper likely made from bamboo that is browned, with many impediments in the paper; it was bound with string. It is $10^{1 / 4}$ inches $(26.04 \mathrm{~cm}) \mathrm{h} \times 5^{3 / 4}$ inches $(14.61 \mathrm{~cm}) \mathrm{w}$ and has fifty-three pages. I bought it in Beijing in 2007.

Zha Fushen 查輔紳.Vol.1, which is fifty-eight pages, is titled “Drafts" [Gaojian 稿件] and is dated 1923, and vol. 2, which is eighty pages, is titled "Lecture Notes" [Jiangyan gao 講 演稿] and is dated 1924. Cha was a teacher at the No. 2 Teacher Training School in Anhui Province [Anhui sheng di'er shifan xuexiao 安徽省立第二師範學校]. This school was 
known for being innovative and incorporating modern methods into its teaching. His family was from Wuyuan 柔源 County, Jiangxi 江西 Province. In addition to the drafts of many letters and a few lesson plans, we find a eulogy [jiwen 祭文] to his grandmother in vol. 2 , pp. $55^{-5}$. The seal on the cover to vol. 2 might have belonged to the writer. It reads: "Held by the study of many perspectives" [Guandizhai zang 觀沓斎藏]. Because these are letters and drafts of letters, the writing style departs from the standard [kaishu 楷書] style and instead follows a running-hand [xingcaoshu 行草書] style. The books are 9 in $(22.86 \mathrm{~cm}) \mathrm{h} \times 7^{1 / 2}$ in $(19.05 \mathrm{~cm})$ w. I bought this set in May 2012 in Hangzhou 杭州. 